\title{
Trust as a Social Basis for International Cooperation Within the Framework of the New Silk Road Concept
}

\author{
Maksim Baranovskiy \\ Department of Sociology, History and Philosophy \\ Financial University under the Government of the Russian \\ Federation \\ Moscow, Russia \\ m.baranovskj@gmail.com
}

\author{
Alexey Borisov \\ Chair of Political Science and Political Philosophy \\ Diplomatic Academy of the Ministry of Foreign Affairs of \\ the Russian Federation \\ Moscow, Russia \\ aborisof@gmail.com
}

\author{
Alexander Romanov \\ English Language Department \\ Military University of the Ministry of Defense of the Russian Federation \\ Moscow, Russia \\ biyalka@mail.ru
}

\begin{abstract}
This paper describes the prospects for crossnational research of trust in the societies of some countriesparticipants of the New Silk Road concept. Trust is considered as an important social aspect in the process of hammering out optimal conditions for effective regional and global political and economic partnership.

Sociological diagnostics of personalized and abstract trust in multicultural societies becomes especially relevant in the framework of interstate dialogue on pressing issues of the global world order. One of the relevant challenges is the "Belt and Road Initiative" megaproject. The scientific support for this discussion should be based on representative results of social-humanitarian, economic and legal research.

The analysis of data obtained from the World Values Survey aggregated database allowed the authors to compare the levels of interpersonal and institutional trust in China, Kazakhstan, Russia, Belarus, Poland and Germany. This research emphasizes the significance of interdisciplinary study of trust aimed to increase the transparency of international cooperation.
\end{abstract}

Keywords: trust, sociological research, comparative research, World Values Survey, international cooperation

\section{INTRODUCTION}

The social phenomenon of trust is the most frequently declared basis for successful international cooperation in today's dynamically changing world. The significance of trust for transnational partnership is emphasized by social science researchers, heads of state, politicians, and economists. Within the scope of the New Silk Road concept as one of the most global, promising and, at the same time, disputable paradigms designed to develop the world dialogue, social aspects of trust should be taken into consideration.
As a basic element of our concept trust is challenging to be factored into the estimation due to the complexity of the results analysis of cross-national sociological research conducted in participating countries. The complexity is conditioned by an ambiguous interpretation and the scale of the New Silk Road spatial boundaries, as well as by the polyparadigmality of the approaches to the definition of its socio-economic format $[1 ; 2]$. Despite the People's Republic of China governmental concept of March 28, 2015 outlined an overall internal and external geographical scope of the Belt Road, the rest of the world is still discussing the megaproject spatial boundaries. Within the scope of this paper we find it expedient to limit ourselves to a comparative analysis of the level of trust in the states linked by the largest Eurasian railway line, bringing together transport networks of China, Kazakhstan, Russia, Belarus, Poland, and Germany [3, pp. 5883]. Economic, social, political, and ideological differences among the states mentioned allow us to make preliminary assumptions on the possibility to create an atmosphere of trust among the countries concerned.

\section{LITERATURE REVIEW AND DESCRIPTION OF RESEARCH METHODOLOGY}

Contemporary studies of the trust phenomenon cover a wide range of special sociological theories $[4 ; 5 ; 6 ; 7 ; 8 ; 9$; 10]. Trust is widespread in all spheres of public life, which makes it relevant to study it in the framework of cross-national surveys. It is noteworthy that despite theoretical, methodological and organizational and technical complexity, the relevance of recent international comparative sociological and socio-humanitarian research has been soaring. The largest 
global research project of this kind is the World Values Study (WVS) with over 50 participating states around the world. Moreover, the scope of the study is constantly expanding [11, p. 133].

The WVS is an international research program focused on relevant issues of scientific and academic study of social, political, economic, religious, and cultural issues from the perspective of human values [12, p. 719]. A questionnaire survey is the main method for studying "World Values". The questionnaire itself includes more than 300 questions reflecting respondents' perception and assessment of various aspects of human and social life. Currently, there have been conducted six rounds of the survey (also referred to as waves) (1984, 1991, 1995, 2001, 2009, 2014) [13, p. 85].

The versatility and thoroughness of the WVS toolkit makes it possible to compare both the development dynamics of various social processes and phenomena in different countries, and match up research results conducted by national research organizations $[14 ; 15 ; 16, \mathrm{p}$. 47]. The sample representativeness and sociological data validity open up a wide range of prospects for mathematical and statistical analysis [17, p. 103]

The WVS database contains sociological indicators to assess levels of interpersonal and institutional trust. In turn, the level of interpersonal trust is measured according to the respondents' reaction to the closed question: "Do you think that most people can be trusted or do you believe that prudence is reasonable when it comes to personal relations?" [18, p. 144]. Confidence in various social institutions is revealed by means of a similar question: "Do you trust political parties, public organizations, etc.?” [18, p. 145].

Results of 6 waves of the World Values Survey (19812014) make up an empirical basis for our research. A comparison of sociological indicators is based on the aggregated database of longitudinal studies. The choice of this data base is conditioned by the fact that projects developed by Chinese experts, including the New Silk Road concept, are large-scale both in terms of space and time. A short-term situational analysis will not allow to carry out further qualitative forecasting of socio-political and economic development.

In our study we have tried for the first time to consider the role of the social phenomenon of trust in international political and economic processes, in particular in the process of implementing the New Silk Road concept.

\section{RESEARCH RESULTS}

The results of the of interpersonal trust level analysis in the participating countries of the New Silk Road indicate that China as an ideological center of the concept has been displaying the most favorable situation for many years (Fig. $1)$.

For the convenience of comparing levels of interpersonal and institutional trust, an index was calculated $\left(I_{I T}=(1 * a+0 * b) /(a+b)\right.$ where, $a, b-$ the results of the answers "most people can be trusted" and "prudence in personal relation is reasonable" to the question: "Do you think that most people can be trusted or do you believe that prudence is reasonable when it comes to personal relations?". In turn, the index values in points from 0 to 1 were distributed as follows: China - 0.57; Germany - 0.39; Kazakhstan - 0.38; Russia 0.29; Belarus - 0.28; Poland -0.23.

A favorable level of interpersonal trust can be conditioned both by the national specifics of social relations, as, for example, in China and Kazakhstan, and by a developed system of social and economic internal interactions among individuals

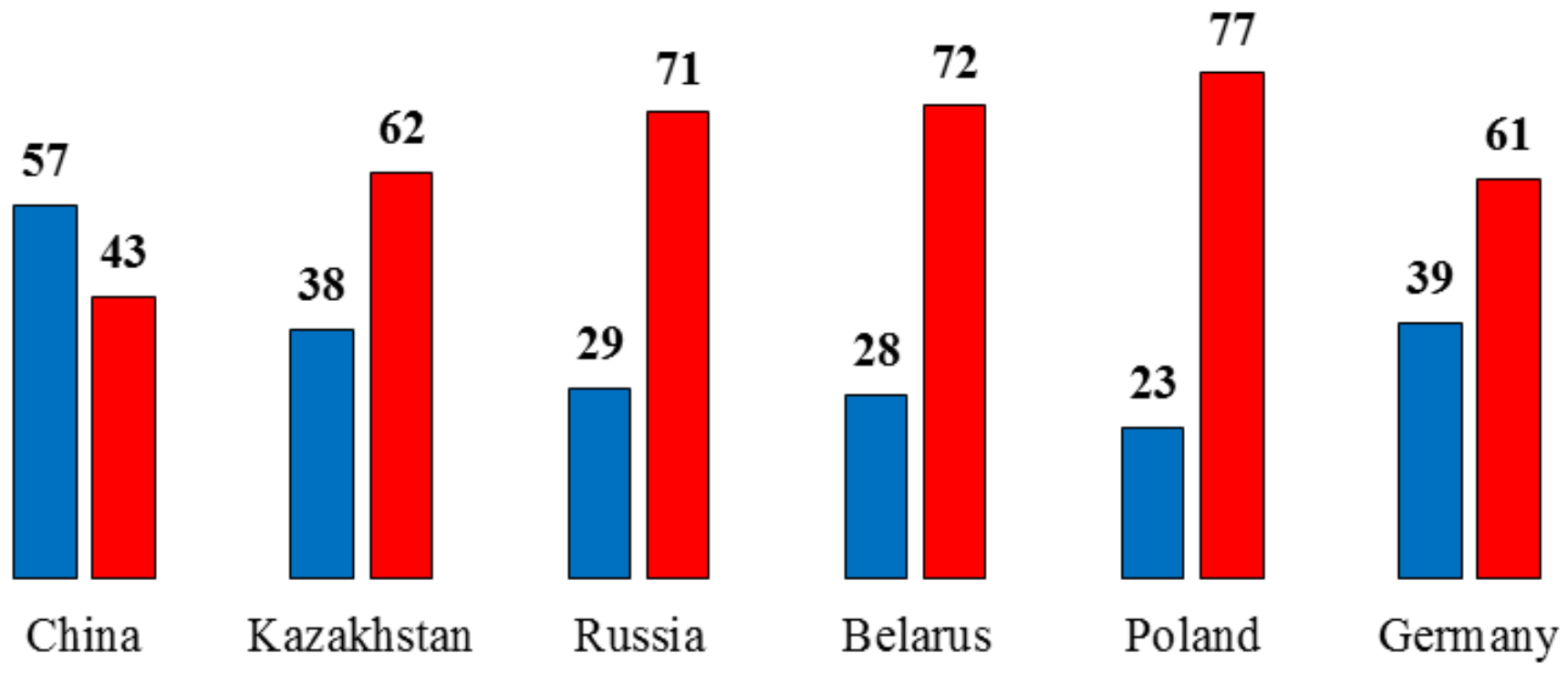

$\square$ Most people can be trusted $\square$ Being careful with people is reasonable

Fig. 1. Level of interpersonal trust in the participating countries (\%) 
TABLE I. SOCIOLOGICAL INDICATORS OF TRUST IN THE SPHERES OF STATE ACTIVITY

\begin{tabular}{|c|c|c|c|}
\hline The scope of the state's activities & Sociological indicator & Indicator & Scale type \\
\hline \multirow{2}{*}{ Public administration } & Level of trust in the government & $\begin{array}{l}\text { Respondent's assessment of the } \\
\text { level of trust in the government }\end{array}$ & Ordinal \\
\hline & Level of trust in Parliament & $\begin{array}{l}\text { Respondent's assessment of the } \\
\text { level of trust in Parliament }\end{array}$ & Ordinal \\
\hline National security & Level of trust in the armed forces & $\begin{array}{l}\text { Respondent's assessment of the } \\
\text { level of trust in the armed forces }\end{array}$ & Ordinal \\
\hline Law-enforcement system & Level of trust in the police & $\begin{array}{l}\text { Respondent's assessment of the } \\
\text { level of trust in the police }\end{array}$ & Ordinal \\
\hline \multirow{2}{*}{ Economic development } & Level of trust in major companies & $\begin{array}{l}\text { Respondent's assessment of the } \\
\text { level of trust in major companies }\end{array}$ & Ordinal \\
\hline & Level of trust in the banking system & $\begin{array}{l}\text { Respondent's assessment of the } \\
\text { level of trust in banks }\end{array}$ & Ordinal \\
\hline $\begin{array}{lll}\begin{array}{l}\text { Cooperation } \\
\text { organizations }\end{array} & \text { with international } \\
\end{array}$ & Level of trust in the United Nations & $\begin{array}{l}\text { Respondent's assessment of the } \\
\text { level of trust in the United Nations }\end{array}$ & Ordinal \\
\hline
\end{tabular}

\section{(Germany).}

According to Chinese sociologists, trust is a key indicator of sustainable development of a socially oriented economy, as well as a key factor to prevent social and financial crises [19, p. 389]. Their approach to measuring interpersonal social trust is more differentiated and somewhat different from that proposed by WVS specialists. In China, seven indicators are used for sociological diagnostics of trust, which are indicated by the following statements: "People in most cases are ready to help each other", "Most people can be trusted", "In most cases people only care about themselves", "I am very cautious about relationships with others", "Most people try to treat others as equals as much as possible", "Most people will take advantage of others at the earliest opportunity", and "Nowadays trust among those around me is relatively high" [20, p.193]. A numerical scale from 1 to 4 presents answer options, where a lower value indicates less social interpersonal trust. The results of the survey conducted in 2013 showed that the average value of interpersonal trust among Chinese residents was about $59 \%$, which is correlated with the results of WVS [20, p.193]. According to the Chinese respondents, justice in the political, economic and educational spheres is the key factor for a high level of interpersonal trust [20, p.194].

Along with interpersonal trust, confidence in abstract systems (institutional trust) plays an important role in creating a favourable atmosphere of domestic and international partnership.

To solve our research problems, we have identified sociological indicators that allow us to assess the level of trust in the areas of public administration, national security, law enforcement, economic development, and international cooperation. This list of indicators is far from exhaustive, but it makes it possible to draw preliminary conclusions about the level of institutional trust in the participating countries mentioned (Table I).

Operationalization of trust in various areas of public activity can serve as a basis for building an institutional trust index $\left(I_{I C}\right)$. The index $\left(I_{I C}\right)$ is presented as an average of the indices characterizing the sociological indicators of trust given in the table. The corresponding indexes are calculated according to the formula $I=(1 * a+0.5 * b+0.25 * c+0 * d) /(a+b+c+d)$ where, $a, b, c, d, e-$ the results of the answers "trust", "rather trust", "rather do not trust" and "do not trust" the questions: "Do you trust... a social institution name...?"

A comparison of the indices showed that the most developed area of state activity in the 6 participating countries is national security, expressed in a high level of public trust in the armed forces (Fig. 2).
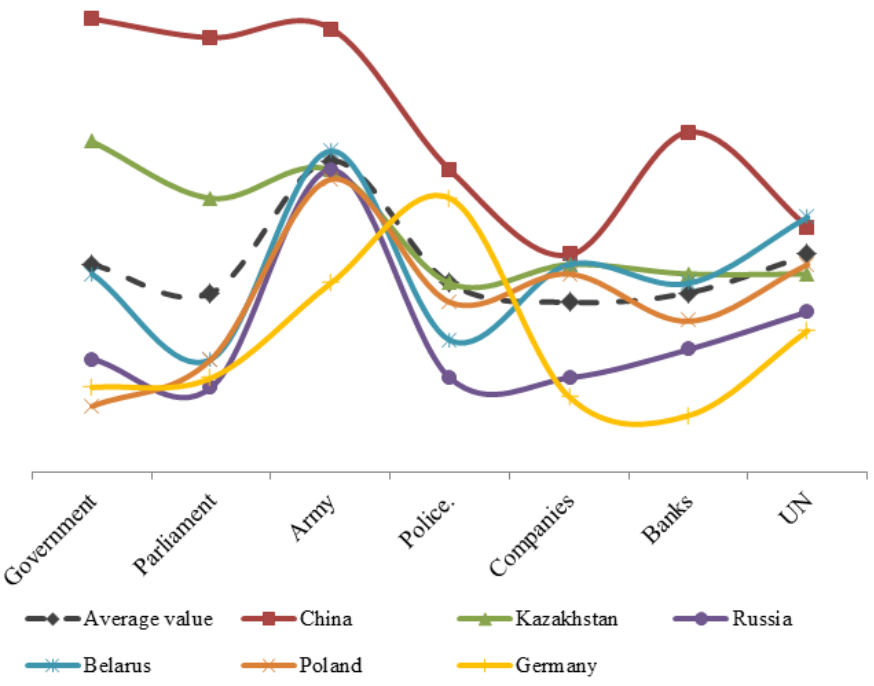

Fig. 2. Level of trust in institutions in participating countries (in scores, 0 to 1 )

China's institutional confidence indexes are higher than the average for all countries, as well as the indexes for each country individually. Chinese citizens have the greatest trust in the institutions of public administration - the government and the parliament - with $40 \%$ and $37 \%$ of respondents fully trusting them. 
Almost all countries except Germany have long enjoyed the trust of their citizens in the national security institution the army.

The most vulnerable areas of state activity are economic development and the law enforcement system. At the same time, each state has its own "weak points", determined by a low level of trust in abstract social institutions.

The level of trust in institutions in five of the six states, except for Germany, is generally in line with the trend line. However, the institutional trust index in Russia, Poland, Belarus and Germany is lower than the average for all countries.

\section{DISCUSSION}

A comparison of interpersonal and abstract trust indices in the six countries once again confirms the existence of an atmosphere of trust among the Chinese population (Fig. 3).

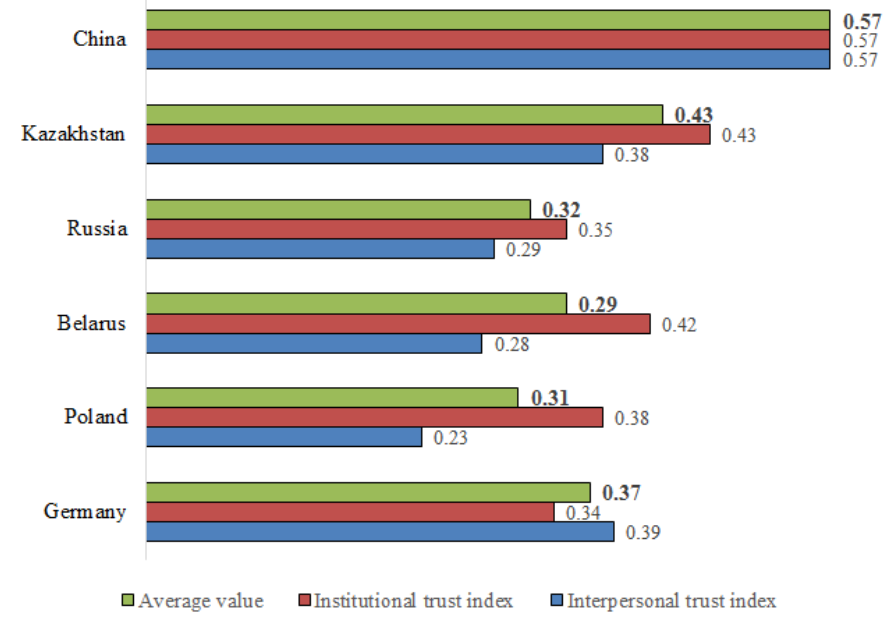

Fig. 3. Comparison of interpersonal trust and institutional trust indices in the participating countries (points, 0 to 1 )

It is noteworthy that the most favorable level of trust is observed in those countries where interpersonal and institutional characteristics of the phenomenon under study are correlated. In turn, distrust in the institutional sphere can lead to destabilization not only of domestic political processes, but also to international tensions.

The social level of trust is also reflected in the behavioral strategies of participants in global international economic and political projects. For example, China, undoubtedly pursuing its financial and public interests, presents the concept of the New Silk Road in a rather transparent manner, proposing to build relationships based on partnership, respect and approval of international activities. Other countries, on the other hand, are cautious about such projects.

\section{CONCLUSION}

The practical significance of the research pertains to relevant sociological reflection on the deep social foundations of global international political and economic processes.
The novelty of the study that distinguishes it from other papers of this kind consists in provisions as follows:

- this research delivers a comparative cross-national sociological analysis of interpersonal and institutional trust in the key countries participating in the New Silk Road concept;

- this paper offers operationalization of sociological indicators of trust in various spheres of state activities;

- this study develops and calculates sociological indices of interpersonal and abstract trust of the population.

Further comparative cross-country trust studies will allow scholars, policymakers and financiers to make more balanced choices about international behavioral strategies and to determine which strategies their global dialogue partners choose.

\section{REFERENCES}

[1] E. M. Azaryan and I. A. Angelina, "Interaction of power and entrepreneur structures as the imperative of the new silk road", RUDN Journal of Economics, 2018, 26 (2), pp. 235-245.

[2] I. A. Zabelina, E. A. Klevakina, and I. S. Denisenko, "Regional structural shifts if the population employment: eastern regions of the new silk road", Tomsk State University Journal of Economics, 2017, no. 39, pp. 80-98.

[3] B. E. Petrovsky et al., "The New Silk Road and its significance for Russia", Moscow: DeLi Plus, 2016, 234 p.

[4] A. M. Almakaeva, "Measurement of generalized (generalized) trust in cross-cultural studies", Sociological research, 2014, no. 11, pp. 32-43.

[5] A. V. Kuchenkova, "Russian intellectuals and institutions: trust or alienation?", Sociological research, 2017, no. 10, pp. 113-121.

[6] V. I. Mukomel and S. V. Ryzhova, "Trust and mistrust in inter-ethnic relations", Sociological research, 2017, no. 1, pp. 37-46.

[7] S. V. Ryzhova, "Trust and ethnic tolerance in the conditions of social change", Sociological journal, 2016, vol. 22, no. 1, pp. 72-94.

[8] P. Yu. Starosta, K. V. Brzezinsky, and V. P. Stolbov, "Structure of social trust in post-industrial cities of Central and Eastern Europe", Sociological research, 2017, no. 12, pp. 79-88.

[9] I. N. Trofimova, "Structure and dynamics of institutional trust in modern Russian society", Sociological research, 2017, no. 5, pp. 68-75.

[10] N. N. Zarubina, A. V. Noskova, and A. L. Temnitsky, "Trust in social science in Russia as a research problem", Sociological research, 2018, no. 7, pp. 105-114.

[11] A. V. Andreenkova, "Inter-country Comparative Studies in Social Sciences: Methodology, Stages of Development, Current State", The World of Russia, 2011, no. 3, pp. 125-154.

[12] C. Haerpfer and K. Kizilova, "The world's largest social science infrastructure and academic survey research program: the World Values Survey in the new independent states", PFUR Newsletter, Series: Sociology, vol. 16, no. 4, pp. 719-741.

[13] L. A. Andreeva and L. K. Andreeva, "Secular or postsecular world? Verification of Concepts", Sociological Studies, 2015, no. 3, pp. 82-88.

[14] L. V. Baeva, "Comparative analysis of values of Russia and Europe in the context of the issues of existential safety", RUDN Journal of Philosophy, 2018, 22 (2), pp. 183-196.

[15] N. A. Golovin, V. Sibirev, "On the Possibility of Cultural Recession in Russia in the 2010s: Reflections on Values Research", Journal of Sociology and Social Anthropology, vol. XIX, no. 3, pp. 80-94.

[16] A. G. Sanina, "Patriotism and Patriotic Education in Modern Russia", Sociological Research, 2016, no. 5, pp. 44-53. 
[19] M. K. Gorshkov and et al., "Middle-income strata of the population in Russia and China: situation, dynamics, features of the worldview", Moscow: NovyiKhronograph, 2018, 544 p.

[17] V. V. Kostenko, "Gender attitudes of Muslim migrants in Western Europe: multilevel non-hierarchical analysis", Monitoring of Public Opinion: Economic and Social Changes, 2017, no. 1, pp. 97-120.

[18] T. V. Merkulova, "Experimental and Sociological Methods of Confidence Measurement", Scientific Works of DonNTU, Series: Economic, 2014, no. 1, pp. 139-148.

[20] M. K. Gorshkov and et al., ""Ideal Society" in People's Dreams in Russia and China", Moscow: NoviyKhronograph, 2016, 424 p. 